\author{
REVIEW OF EUROPEAN AND COMPARATIVE LAW \\ VOLUME XLII \\ YEAR 2020, ISSUE 3, pp. 7-49 \\ DOI: https://doi.org/10.31743/recl.4997
}

\title{
THE SUBNATIONAL DIMENSION OF EUROPEANIZATION
}

\author{
Dana Dobrić Jambrović*, Mariela Marešic ${ }^{* *}$
}

\begin{abstract}
Despite the increasing influence of European legislation on the subnational level of government and local public policy, until recently, the subnational level has played only a marginal role in exploring Europeanization processes. With the creation of the single market in the early 1990s, the process of European integration began to have a significant impact on local governments across Europe. Subsequently, the development of European regional and cohesion policy resulted in the adaptation of the political and administrative structures of the local units of the Member States. However, the impact of European integration is not one-sided. The European Union's multilevel governance system and the spread of the impact of Europeanization on interstate levels pose new challenges for European cities and local actors and enable them to actively participate and influence political decision-making processes at the European level. The main aim of the paper is to identify, explain and classify aspects of Europeanization of local self-government. Therefore, research questions include identifying the dimensions, mechanisms and adjustments that local units make under the influence of European institutions. The paper first conceptualizes the phenomenon of Europeanization and then identifies and addresses its dimensions and mechanisms in the field of local self-government. Emphasis is placed on the implementation of European
\end{abstract}

* Ph.D. Dana Dobrić Jambrović, Assist. Prof., University of Rijeka, Faculty of Law, Chair of Administrative Science, Republic of Croatia, ddobric@pravri.hr, ORCID: 0000-0002-9131-5846.

** Mariela Marešić, graduate student enrolled in the Specialist Graduate Professional Study Programme in Public Administration, University of Rijeka, Faculty of Law, mmaresic@pravri.hr, ORCID: 0000-0002-5471-4397. 
legislation by local authorities and the institutional and non-institutional (indirect and direct) participation of subnational units in European governance. In an attempt to provide answers to research questions, the authors applied the theoretical approaches of political sciences, sociology and international relations, and also the teleological and linguistic method.

Keywords: Europeanization, local government, paradiplomacy, institutional changes, networking

\section{INTRODUCTORY REMARKS ON EUROPEANIZATION}

Europeanization, as a topical issue, is addressed within a number of disciplines and in different contexts. The ever-increasing number of books, articles, research, projects, and conferences is dedicated to the phenomenon of Europeanization ${ }^{1}$. It is justified to characterize Europeanization as a phenomenon since it is attributed to many meanings and encompasses a number of processes. According to Harmsen ${ }^{2}$, Europeanization as a political process actually encompasses two processes that are simultaneously occurring and running in parallel, namely the creation of a European community, i.e., new levels of governance (bottom-up approach), and the adaptation of national policies to the process of European integration (topdown approach). However, within the social sciences, a whole range of meanings of Europeanization is addressed and problematized.

Firstly, Europeanization implies the emergence of new institutional and functional forms of European rule. In this interpretation of Europeanization, the emphasis is placed on the European Union. However, Europeanization should not be seen as synonymous with the process of European integration, but rather as a concept that encompasses how this

1 The following journals may be highlighted among those dealing with Europeanization: Comparative European Politics, European Journal of Political Research, Governance, Journal of Common Market Studies, Journal of European Integration, Journal of European Public Policy, Living Reviews in European Governance, Public Administration, Public Policy and Administration, Queen's Papers On Europeanisation.

2 Robert Harmsen, "Europeanization and Governance: A New Institutionalist Perspective", in Europeanization, Institutions, Identities and Citizenship, eds. Robert Harmsen, Thomas M. Wilson, Amsterdam-Atlanta: Rodopi, 2000, 52. 
process has redefined the conceptions of governance at the national and supranational level. It is about creating a hub for collective action that, in addition, should ensure a certain degree of coordination and coherence. Europeanization, therefore, represents the emergence and development of political, legal, and social institutions at the European level that formalize interactions between different actors, as well as the emergence of policy networks specialized in the creation of relevant EU rules.

Secondly, Europeanization represents the adaptation of national institutional structures and decision-making processes on public policies to the development of European integration, i.e., political and economic developments at the EU level. Each multi-level governance system requires the division of powers and responsibilities between different levels and must, among other things, ensure a balance between unity and diversity, central coordination, and local autonomy ${ }^{3}$. From an institutional perspective, the processes of experimental learning and competitive selection do not always produce perfect results in terms of automatic, continuous, and accurate adaptation. Adaptation requests are often not well received by the Member States, or the adaptation process is not monitored to the necessary extent. Also, the degree of adaptation is often inconsistent with the degree of change to which institutions should adapt, and there may be no optimal institutional response to environmental change. The most common case is the selection of one practice from the existing repertoire that could be used. These requirements are interpreted and modified by national authorities in accordance with their traditions, institutions, identities, and resources, thereby limiting the degree of convergence and homogenization. In Europeanization research, the focus is on determining the measure of convergence of domestic institutions and the decision-making process of the European model. A key issue that needs to be addressed is whether the Member States converge with interstate negotiations or take on an increasingly European model. ${ }^{4}$

3 Johan P. Olsen, "The Many Faces of Europeanization”, Journal of Common Market Studies, 5(2002): 924, https://doi.org/10.1111/1468-5965.00403.

4 European institutions and the decision-making process evolve differently within different institutional spheres and areas of public policy. Therefore, there are differences in pressure for the Member States to adapt as well as in their responses to these pressures, i.e., their ways of adaptation. The impact of adaptation pressures in a particular country will 
Thirdly, Europeanization also signifies public policy coherence. In this context, the concept of isomorphism gains in prominence whereby organizations "cope with their environment at the borders and mimic environmental elements in their structures"s. In doing so, organizations apply a defensive strategy against pressures from the relevant environment, leading them to an isomorphic transformation. This includes: (1) adopting structural forms or elements of an organizational structure for their external legitimacy, not for reasons of efficiency ${ }^{6}$. (2) adopting external criteria for evaluating the value of structural elements that legitimize an organization and assess its social suitability, and (3) stabilizing external and internal organizational relationships by relying on organizations to be legitimized from the outside, which leads to isomorphism and reduction of turbulence ${ }^{7}$. In this respect, a distinction is made between the direct and

depend on the legal basis of the change, whether it relies on binding norms (hard law) or informal sources of law (soft law), and whether the actors who need to implement them are involved in determining concrete measures, the economic and financial capacity of each country, etc. Also important is the attitude of national authorities towards European demands/pressures. Some countries are proud of their historical achievements and seek to protect their traditions, while others want to dispose of the burden of the past.

5 Anamarija Musa, Agencijski model javne uprave, Zagreb: Pravni fakultet Sveučilišta u Zagrebu, Studijski centar za javnu upravu i javne financije, 2014, 44.

6 The success of an organization does not depend on the effectiveness of its operations but the degree of isomorphism with respect to the institutional environment, whereby it gains legitimacy and resources. (John W. Meyer, Brian Rowan, "Institutionalized Organizations: Formal Structure as Myth and Ceremony", in The New Institutionalism in Organizational Analysis, eds. Walter W. Powell, Paul J. DiMaggio, Chicago-London: The University of Chicago Press, 1991: 43.)

7 DiMaggio and Powell distinguish three mechanisms of isomorphic institutional change. The forced isomorphism of organizations is due to the formal and informal pressures exerted by other organizations on which they depend and due to certain cultural expectations in society. The pressures come in the form of legal regulations, non-binding rules, and guidelines that point to subtler changes. Mimetic isomorphism involves taking on "the usual responses to organizational technology uncertainty, ambiguity about goals, environmental trends, etc.". Organizations take on the solutions of those organizations in their field that they deem more legitimate or successful. Finally, normative isomorphism is defined as "the collective effort of members of the profession to define the conditions and methods of work, control the creation of professionals, and establish the cognitive basis and legitimacy for their professional autonomy". (Anamarija Musa, Agencijski model javne uprave, Zagreb: Pravni fakultet Sveučilišta u Zagrebu, Studijski centar za javnu upravu i javne financije, 2014, 46-47.) 
indirect Europeanization of public policies. In the first case, Europeanization is accomplished by delegating the regulatory powers of the Member States to the European Union, and, in the second case and to a different extent, by means of mutual adaptation of certain public policies and/or regulatory frameworks of the Member States 8

Apart from the fact that the process of Europeanization imposes a number of problems on national political systems, it can also open up new possibilities for deciding issues that fall outside national boundaries. Member State governments must find a way to reconcile all potentially contradictory pressures coming from national and European levels. Although one of the principles of EU policy is the protection of fundamental national interests, certain Member States are compelled, in certain circumstances, to implement public policies that do not have support within the national political system. In such cases, Europeanization is a form of external restriction on the domestic order. On the other hand, there is often a situation where the ruling elite, under the pretext of EU-made demands ("Europe Made Me Do It!") and in pursuit of their own interests, seeks to implement certain policies that they would not otherwise be able to impose at the national level.

In terms of geographically peripheral and less economically developed EU Member States, Europeanization can also be seen as a modernization process that involves a number of structural transformation measures. Such measures are implemented to bring less developed countries closer to the economic and political model prevailing in more advanced and influential Member States. The structural measures are aimed at reducing the overall administrative system, involving the voluntary, non-profit sector in public affairs, and loosening the links in the rest of the system (referring to political and administrative decentralization, separation of political affairs from routine, executive tasks, functional independence of public services, etc.) $)^{9}$.

8 Robert Harmsen, Thomas M. Wilson, "Introduction: Approches to Europeanization", in Europeanization, Institutions, Identities and Citizenship, eds. Robert Harmsen, Thomas M. Wilson, Amsterdam-Atlanta: Rodopi, 2000, 15.

9 Following the crisis of the welfare state and the penetration of the concept of the neoliberal model of governance, there is a change in the understanding of the role of the state and the relationship between the state and the market. The focus has been shifted from "a system of clearly separated institutions and functions and a hierarchical principle" to "network 
Furthermore, Europeanization can be considered in the context of $E U$ enlargement. States are requested to adopt the acquis communautaire, to meet the political criteria ${ }^{10}$ and administrative standards based on which their progress is assessed on an annual basis. According to Schimmelfennig and Sedelmeier, institutional change is most often driven by a model of external incentives based on conditionality policy. It is a model in which Europeanization is initiated by the Union with "the use of positive conditional incentives (ultimately EU membership) as a reward for countries adopting certain EU-specified rules"11.

management with intertwined functions and actors". Under the influence of the new public management doctrine, the welfare state is transformed into a regulatory one, with a significant institutional change in the form of "retreat of the state." However, this does not imply the withdrawal of the state entirely, but a change of its functions. From the previous role of the holder of the command and control functions, the state becomes an active stakeholder of various forms of interaction and cooperation at multiple levels of governance. Within the European Union, Member States continue to have instruments of command while the Union relies on the regulation and functioning of regulatory agencies as a new institutional model of governance. Thus, the Union has instruments of regulation that can be classified into: (1) binding - primary (founding contracts) and secondary legislation (regulations, directives, decisions), (2) non-binding - recommendations, resolutions, declarations, and (3) activities such as organizing conferences, designing studies, disseminating good practice, etc. Although not legally binding, soft law regulations are regulating an increasing number of public policies, especially in areas where the Union is not authorized to act through classical regulatory instruments. Since the adoption of the White Paper on the completion of the internal market, the Commission has been proclaiming to focus more on regulation through the open method of coordination and, as a new approach, has promoted regulation through a combination of uniform objectives and flexible means. (Anamarija Musa, Agencijski model javne uprave, Zagreb: Pravni fakultet Sveučilišta u Zagrebu, Studijski centar za javnu upravu i javne financije, 2014, 104.)

10 There are four sets of political criteria: 1) the Copenhagen criterion (1993) requires the construction or strengthening of institutions that will guarantee democracy, the rule of law and human rights, 2) the Madrid criterion (1995) focuses on adapting administrative and judicial structures, 3) the Luxembourg criterion (1997) on strengthening and improving institutions with a view to achieving greater reliability, and 4) the Helsinki criterion (1999) establishes an obligation to adopt the values and objectives of the Founding Agreements. (Francisco Cardona Peretó, Anke Freibert, "The European Administrative Space and SIGMA Assessments of EU Candidate Countries", Hrvatska javna uprava, 1(2007), 56.)

11 Frank Schimmelfennig, Ulrich Sedelmeier, "The Europeanization of Eastern Europe: the External Incentives Model Revisited”, Paper for the JMF@25 conference, EUI, 
The broadest notion of Europeanization refers to the transformation of identity at the European level in a way that relativizes the importance of national identity. Changes occur because of the two-dimensionality of identity. The first dimension is cumulative and refers to the individual's disposition to feel a sense of belonging to more than one group. The second is characterized by exclusivity, which is a direct consequence of the actions of national political elites seeking to preserve their power and decision-making authority. According to Eurobarometer $(2018)^{12}$, the citizens of the Member States are still more connected to the country in which they live (93\%) than to the European Union (56\%). 89\% of the citizens feel a sense of belonging to the local community and the region ${ }^{13}$.

Finally, Europeanization can signify transnationalism ${ }^{14}$ and cultural integration. In this context, Europeanization refers to the areas of interaction that the citizens of Europe encounter daily. Such interpersonal interactions are a reflection of transnational and intercultural relations that are being strengthened by globalization and European integration. Emphasis is placed on maintaining and crossing borders, both in terms of cultural

22/23 June 2017, https://www.eui.eu/Documents/RSCAS/JMF-25-Presentation/Schimmelfennig-Sedelmeier-External-Incentives-Revisited-JMF.pdf.

12 Standard Eurobarometer 89, Report on European Citizenship, Spring 2018.

13 For more about the relationship between the European and national identity, see Richard K. Hermann, Thomas Risse, Marilyn B. Brewer, Transnational Identities: Becoming European in the EU, Oxford: Rowman \& Littlefield, 2004; Michael Bruter, Citizens of Europe? The Emergence of a Mass European Identity, Houndmills. Basingstoke: Palgrave Macmillan, 2005; Paul Magnette, „How can one be European? Reflections on the Pillars of European Civic Identity“, European Law Journal, 5(2007); James A. Caporaso, Min-hyung Kim, "The dual nature of European identity: subjective awareness and coherence", Journal of European Public Policy, 1(2008).)

${ }_{14}$ Transnationalism is a term that was first used in the study of migration and referred to the activities of migrant groups that resulted in the relativization of basic features of the nation-state. Today, the term transnationalism is interpreted very extensively and encompasses a number of multinational, transnational, and transnational phenomena that lead to nation-state transformation. Transnational activities are primarily carried out by non-institutional actors, such as numerous international non-governmental organizations, which, by acting on the global political scene, diminish the meaning of nation-state borders. They also create extraterritorial zones where access to state institutions is hampered. (Saša, Božić, “Nacionalizam-nacija, „transnacionalizam“-,transnacija“: mogućnosti terminološkog usklađivanja”, Revija za sociologiju, 3-4(2004):188.) 
and political identity, and in terms of legal, political, and administrative borders between the states.

The concept of Europeanization can, in addition to the processes that take place vertically, between the EU and the Member States, also include the horizontal transfer of ideas and good practices between European countries, whether or not they are Member States ${ }^{15}$. In horizontal transfers, the EU can play a role in facilitating such processes. Europeanization may also involve the transfer of European political ideas and practices outside of Europe ${ }^{16}$. For example, the Treaty of Lisbon emphasizes the need to develop, represent, and globally expand the European model of society ${ }^{17}$. The White Paper on European Governance proposes to promote EU goals globally, which would make the Union stronger at the global level ${ }^{18}$.

Although the definitions and applications of the term Europeanization mentioned above are quite different from one another, they each contribute in their way to a better understanding of the EU and its impact on the Member States. They also point to different aspects of political and social change in contemporary Europe. In other words, Europeanization means the totality of transformations of local, regional, national, and international structures and relations of government, i.e., the process of becoming and

15 European countries make decisions about their actions by looking at each other, looking for role models, and copying each other, which results in the diffusion of specific institutional and functional models and practices. The consequence is an isomorphic transformation as a basis for realizing the legitimacy of European countries.

16 This is cultural dissemination of patterns, institutions, ideas, and principles typical of Europe beyond the borders of the EU, through a process of diffusion that depends on the "interaction of the external impulses and internal institutional traditions and historical expectations" of each country. (Johan P. Olsen, "The Many Faces of Europeanization”, Journal of Common Market Studies, 5(2002):938, https://doi.org/10.1111/1468-5965.00403.) The cultural notion of Europeanization comes to light in two contexts. First, in the context of EU enlargement, when the countries of Eastern Europe seek to make up for lagging behind the West and to meet EU membership requirements. Secondly, in the context of the European Neighborhood Policy, the realization of certain forms of cooperation is conditional on the adoption of European values and norms by countries located along the EU's immediate borders, which have no interest in becoming a member.

17 European Union. 2007. Treaty of Lisbon. OJ C 306, 17. 12. 2007.

18 "Successful international action reinforces European identity and the importance of shared values within the Union." (Commission of European Communities: European Governance. A White Paper. Brussels 25. 7. 2001. COM (2001) 428 final.). 
being increasingly "European". This is achieved by changing the mode of action within and between individual state bodies, or more broadly, the actions of politicians, civil servants, entrepreneurs, farmers, etc.

\section{CONCEPTUALIZATION OF THE EUROPEANIZATION PROCESS}

The first approach to research on the phenomenon of Europeanization was to examine the impact of European integration on lower levels of governance, i.e., the structures, processes, and public policies in the Member States (top-down approach), while later studies have highlighted the importance of upward Europeanization, i.e., the transfer of ideas and practices from the Member States to the supranational level (bottom-up approach) ${ }^{19}$. Despite the clear focus on downward causation research, Europeanization as a two-way process is a widely accepted view. Featherstone and Kazamias emphasize that the Member States are not only passive recipients of the European impact and that domestic and EU institutional arrangements are characterized by the interconnectedness and involvement of actors in vertical and horizontal networks. Interaction between the Member States and the EU involves, on the one hand, the transmission of preferences of subnational levels to the European level and, on the other, their adaptation to pressures from the European level and the implementation of European public policies ${ }^{20}$.

The Europeanization process can be classified into three categories. The content of each category needs to be analyzed separately and then comparatively in order to develop a complete concept of Europeanization.

Top-down Europeanization (En1) seeks to explain the conditions and causal mechanisms by which the European Union causes change at the level of the Member States and third countries. The starting view is that Eu-

19 Tomasz P. Woźniakowski, Frank Schimmelfennig, Michał Matlak, "Europeanization Revised: An Introduction", in Europeanization Revised: Central and Eastern Europe in the European Union, eds. Michał Matlak, Frank Schimmelfennig, Tomasz P. Woźniakowski, European University Institute, Robert Schuman Centre for Advanced Studies, 2018., 7-8.

20 Kevin Featherstone, George Kazamias, "Introduction: Southern Europe and the Process of 'Europeanization"', South European Society and Politics, 2(2000): 10, https:// www.tandfonline.com/doi/pdf/10.1080/13608740508539600?needAccess=true. 
ropean norms lead to domestic changes ${ }^{21}$ but not the convergence of national structures, processes, and public policies. If there are misfits between European and subnational levels, the impact of the EU can be explained by the theory of institutionalism of rational choice and sociological institutionalism. Representatives of both theories agree that institutions play a key role as mediators between European influences and domestic systems but differ in their interpretation of how institutions fulfill this role ${ }^{22}$.

21 The term 'domestic changes' is used to refer to the changes that the Europeanization process is causing not only at national but also at subnational levels of government (regional and local). In a broad sense, the term may also include non-state actors (civil society organizations and the private sector).

22 According to the institutionalism of rational choice, the EU encourages the adaptation of subnational levels by changing opportunity structures for domestic actors. (Christoph Knill, Dirk Lehmkuhl, "How Europe Matters: Different Mechanisms of Europeanization", European Integration Online Papers, 7(1999): 3, https://papers.ssrn.com/ sol3/papers.cfm?abstract_id=302746) This does not involve directly prescribing their institutional set-up but indirectly changing the constellation of domestic actors involved in the political decision-making process by influencing the EU on the distribution of power and resources between them (Birgit Sitterman, Europeanization - A Step Forward in Understanding Europe, 2006, https://ceses.cuni.cz/CESES-141-version1-2_1_Sittermann_Nachwuchsgruppe_on_Europeanisation_2006.pdf.) The existence of discrepancies between European and national norms requires domestic adaptation in terms of downloading EU policies and institutions. The conditions and modalities for adaptation are defined based on a cost-benefit analysis conducted by interested stakeholders, i.e., all those whose interests are affected by the downloading process. In doing so, institutions facilitate or restrict certain actions of domestic actors by making some options more expensive than others. From this perspective, Europeanization is mainly conceived as a political opportunity structure that offers some actors additional resources to exert influence, while significantly limiting others to achieving their goals (Tanja A. Börzel, Diana Panke, "Europeanization", in European Union politics, eds. Michelle Cini, Nives Perez-Solorzano Borragan, Oxford: Oxford University Press, 2010, 411.)

The theory of sociological institutionalism explains that the mechanisms of change are based on the cognitive and normative processes involved in top-down Europeanization, and it relies on a logic of appropriateness, which implies that actors are guided by shared values and perceptions of right and socially acceptable behavior. Such shared beliefs significantly influence the way domestic actors define their goals and their understanding of rational action. Europeanization is therefore understood as the emergence of new rules, norms, procedures, and opinions that the Member States must implement into the domestic structure. If there is a discrepancy, it is the task of epistemic communities and advocacy coalitions to socialize domestic actors through persuasion and social learning models into 
Bottom-up Europeanization (En2) analyzes the process of preference uploading of domestic actors to the European level. Preferences may relate to the functional (public policies), process (political processes), or structural (institutions) dimension. Theoretical approaches that study upward Europeanization and are compatible with one another are rationalism and constructivism. The basic premise of a rationalist approach is that domestic actors pre-define their interests according to a cost-benefit analysis of the various options and then seek to achieve them by relying on their own sources of power, such as financial capacity or the number of votes in the European Council23. Constructivists, on the other hand, believe that the preferences of state and non-state actors are not entirely predetermined, but may be reversed in the case of valid and strong counter-arguments. Domestic actors have an idea of what they want. However, there is a potential to change their preferences in the course of negotiations at the European level if other actors make convincing claims, such as new scientific insights ${ }^{24}$.

In this context, Börzel highlights three different strategies that the Member States apply when representing national interests in competition for European policies. The "Pace-Setting" strategy involves an active shaping of European policies in accordance with the domestic preferences of

a new system of suitability norms and rules so that they can adequately adjust their interests and identities. It should be noted that the stronger the cooperation of informal institutions in the Member States, the more likely there will be changes in the domestic system (ibid.).

23 Countries with more votes and higher bargaining power are in a better position during the political decision-making process. More powerful states will have more influence in shaping European policies, especially if they succeed in forming "winning" coalitions. Some countries, however, use coercion to achieve their goals. For example, they threaten other countries by interrupting further cooperation, denying support in other matters, reducing additional payments, etc. Subnational authorities are also, to a greater or lesser extent, engaged at the European level and exert their influence on the decision-making process through multiple access points (see infra), lobbying, and participating in the activities of the trans-regional networks of which they are members.

24 According to this approach, the policy outcomes and dynamics of integration depend on the process of discussion between the Member States, supranational institutions and policy experts, and epistemic communities. That argument, which wins within the contest of different ideas, will affect the policy outcome. States will be more successful in shaping public policies as their arguments align with the values and ideas of other actors (ibid.). 
each Member State. They "export” domestic public policies to the European level that are subsequently adopted by other countries. Member States that choose to apply this strategy should have sufficient capacity to successfully negotiate and stand up to the opposition of Member States with divergent policy preferences. The second is "Foot-Dragging," a strategy that aims to obstruct or delay the uploading of public policies by other Member States to avoid implementation costs. Finally, the "Fence-Sitting" strategy is ambivalent and aimed at tactically forming coalitions with the first two groups of Member States or, in turn, taking a neutral position depending on the issue ${ }^{25}$.

The practices of Member States' public policies are being consolidated at the European level through micro and macro uploading and integration procedures. This is followed by downloading and micro and macro crossloading (En3) of consolidated content into domestic discourse, political structures, and public policies. The macro aspect refers to the mechanisms of positive integration and the micro aspect to the mechanisms of negative integration. Positive integration represents the EU activities in creating a supranational model of public policy that the Member States need to implement through appropriate legal regulation. Negative integration involves creating an efficient market, not by sectoral regulation, but by removing obstacles ${ }^{26}$. The concept of crossloading introduces a horizontal dimension to the concept of Europeanization ${ }^{27}$. Macro crossloading represents mutual learning and procedures that take place between national authorities, and micro crossloading subnational interaction and learning

25 Tanja A. Börzel, "Shaping and Taking EU Policies: Member State Responses to Europeanization”, Queen's Papers on Europeanisation 2(2003): 8, http://citeseerx.ist.psu.edu/ viewdoc/download?doi=10.1.1.535.1021\&rep=rep1 \&type=pdf.

26 Anamarija Musa, Agencijski model javne uprave, Zagreb: Pravni fakultet Sveučilišta u Zagrebu, Studijski centar za javnu upravu i javne financije, 2014, 252. Also see: Laszlo Bruszt, Visnja Vukov, "Making states for the single market: European integration and the reshaping of economic states in the Southern and Eastern peripheries of Europe", West European Politics 4(2017):663-687.

27 Graeme Crouch, "New Ways of Influence: 'Horizontal Europeanization in Southeast Europe", in Europeanization Revised: Central and Eastern Europe in the European Union, eds. Michał Matlak, Frank Schimmelfennig, Tomasz P. Woźniakowski, European University Institute, Robert Schuman Centre for Advanced Studies, 2018., 41. 
through group mediations. With prior coordination of policy areas, learning leads to integration. The values, norms, beliefs, procedures, policy processes, and possibly the discourse and ideology of subnational levels of government are integrated ${ }^{28}$.

\section{DIMENSIONS OF THE IMPACT OF EUROPEANIZATION ON DOMESTIC STRUCTURES}

In exploring the effects of Europeanization processes, changes in the structure of the Member States can be identified in three dimensions: process (political processes; politics), functional (public policies; politics), and

28 Crossloading Europeanization (En3) is explored in the context of policy transfers that can be vertical and horizontal. The vertical policy transfer (VPT) is linked to EU policy and European integration processes, while the horizontal (HPT) involves the process of learning and equalizing public policies between the Member States without the involvement of European institutions. It is generally accepted that policy transfer is understood as Europeanization, provided that the European institutions participate in the process, even if it involves only their coordinating function. It follows that vertical policy transfer is taken as explicit Europeanization, which cannot be said of the horizontal policy. If the horizontal policy transfer is also defined as Europeanization, its conceptual stretching is expanding. (Elizabeth Bomberg, John Peterson, "Policy Transfer and Europeanization: Passing the Heineken Test?", Queen's Papers on Europeanisation 2(2000):5, http://www.qub. ac.uk/schools/SchoolofPoliticsInternationalStudiesandPhilos ophy/FileStore/EuropeanisationFiles/Filetoupload,38445,en.pdf.) The horizontal policy transfer does not necessarily involve Europeanization. However, if this happens, En 3 will not be as explicit as in the case of vertical policy transfers. However, horizontally transposed public policies may become the norm to be applied at the EU level if the Member States carry out their uploading (En2) in the EU domain. Subsequently, based on the interaction between En2 and European integration, policy outcomes are eventually transferred to the national domain (En1) where their cultural interpretation takes place. Also, any cultural interpretation by the Member States can lead to further En3 in terms of the vertical policy transfer, and again, En2 and European integration. Therefore, HPT is a driver of change, occurring only in the initial phase of the policy transfer through the EU system, and is considered the 'content' of Europeanization. On the other hand, VPT, or En3 in the narrower sense, is the outcome of the top-down Europeanization and is considered to be part of the 'Europeanization' process. (Kerry E. Howell, „Developing Conceptualisations of Europeanization: Synthesising Methodological Approaches", Queen's Papers on Europeanisation 3(2004):9, http:// citeseerx.ist.psu.edu/viewdoc/download?doi=10.1.1.496.9117\&rep=rep1\&type=pdf.) 
structural (political structures; polity) ${ }^{29}$. The demarcation of these dimensions is made solely for analytical purposes, while in reality, there is an interplay of their elements.

Table 1: Domestic structures influenced by Europeanization

\begin{tabular}{|c|c|c|c|}
\hline \multicolumn{4}{|c|}{ Europeanization dimensions } \\
\hline \multicolumn{2}{|c|}{$\begin{array}{c}\text { POLITICS } \\
\text { (political processes) }\end{array}$} & $\begin{array}{c}\text { POLICY } \\
\text { (public policies) }\end{array}$ & $\begin{array}{c}\text { POLITY } \\
\text { (political structures) }\end{array}$ \\
\hline \multirow{4}{*}{$\begin{array}{l}\text { Political } \\
\text { parties } \\
\text { and interest } \\
\text { groups }\end{array}$} & Interest formation & Standards & Political institutions \\
\hline & $\begin{array}{l}\text { Aggregation of } \\
\text { interests }\end{array}$ & Instruments & $\begin{array}{l}\text { Intergovernmental } \\
\text { relations }\end{array}$ \\
\hline & $\begin{array}{l}\text { Representation of } \\
\text { interest }\end{array}$ & $\begin{array}{l}\text { Approaches to problem } \\
\text { solving }\end{array}$ & Judiciary \\
\hline & Public debates & $\begin{array}{l}\text { Discussions on public } \\
\text { policies }\end{array}$ & Public administration \\
\hline & & & State traditions \\
\hline & & & Economic institutions \\
\hline & & & $\begin{array}{l}\text { Relations between } \\
\text { the state and society }\end{array}$ \\
\hline & & & Collective identities \\
\hline
\end{tabular}

Source: adapted from Börzel and Risse $e^{30}$

29 By political processes, Katenhusen and Lamping imply structures of formation, aggregation, mediation, and representation of interests and public discourse. Public policies relate to policy content, instruments, and styles, as well as approaches to problem solving. Political institutions include political rules and decision-making procedures, legal and administrative structures, systems of territorial organization, national tradition and identity, and the economy. (Sošić, Mario. "Europeizacija nacionalnih politika: concept i istraživački pristup”, Anali hrvatskog politološkog društva 1(2006):238.)

30 Tanja A. Börzel, Thomas Risse, "Conceptualizing the Domestic Impact of Europe”, in The Politics of Europeanization, eds. Kevin Fetherstone, Claudio M. Radaelli, Oxford: Oxford University Press, 2003, 60. 
The dimension of political processes is a very heterogeneous area in which we find a connection between EU and domestic political activities. The term "politics" is extremely broadly defined and can most easily be defined as the area of activity of individual and collective actors aimed at supporting or challenging domestic public policies and other activities, as well as expressing their interests. There are many forms of conducting such activities: voting in elections and referendums, polling, social movements, interest groups, political parties, etc. ${ }^{31}$. However, compared to the actors of the other two dimensions, those mentioned above have little or no formal interaction with $\mathrm{EU}$ institutions or the decision-making process at the supranational level. Thus, the impact of Europeanization on the Member States' political processes is indirect.

In the public policy dimension, it is easiest to see the impact of the EU. EU legislative activity is mainly related to the regulation of the internal market so that public policy is generally characterized by an economic and regulatory, and less social and redistributive character. In doing so, the European Commission most often applies the traditional method of action, also called the direct or "hard" method. Binding regulation is made based on public policy proposals formulated in accordance with the outcomes of intergovernmental negotiations ${ }^{32}$. However,

31 Robert Ladrech, Europeanization and National Politics, The European Union Series: Palgrave Macmillan, 2010, 23.

32 Under the Treaty of Lisbon, EU institutions adopt two types of acts. Legislative acts (Article 289 (3) TFEU) are adopted in the ordinary (Article 289, paragraph 1 TFEU) and special legislative procedure (Article 289 (2) TFEU) and at the initiative of a group of Member States or the European Parliament at the recommendation of the European Central Bank or at the request of the Court or of the European Investment Bank in the specific cases provided for in the Treaties (Article 289, paragraph 4 TFEU). As legislative acts, directives are fully binding and directly applicable in all Member States (Article 288, paragraph 2 TFEU). They completely replace existing national standards in order to harmonize the legal systems of the Member States. Directives are binding with regards to the objective to be achieved, while the way to achieve it (e.g., passing a new law, amending the existing law, passing a by-law) is left to the discretion of the Member States. Therefore, their purpose is not to equalize but to approximate national rights. (Ivan Koprić et al. Europski upravni prostor, Zagreb: Institut za javnu upravu, 2012, 78.) Decisions, being the third category of legislation, are fully binding to those to whom they are addressed, including natural persons. (Trevor C. Hartley, Temelji prava Europske zajednice, Rijeka: 
the traditional method is complemented by the so-called Open Method of Coordination (OMK) as a "soft" method. Member States seek to coordinate national policies and ensure the achievement of European policy objectives through mutual cooperation and the exchange of information and good practice, while the European Commission emerges as an advisor and promoter of ideas. The outcomes of such initiatives are not legally binding, but it is up to the Member States to refine and implement the policy proposals.

The dimension of domestic political institutions is also a broad area of research that covers national and subnational political institutions, their mutual relations, central government, relations between the legislative and executive branches of government, and the judiciary. Changes visible at the central government level are, for example, an increase in the role of the Prime Minister, the emergence of new coordinating bodies and organizational units within the ministry responsible for EU policy affairs ${ }^{33}$. Also, Europeanization processes can refer to constitutional changes in terms of the ratification of EU fundamental treaties, a change in the nature of relations between central and subnational governments, and the formation of EU affairs committees within representative bodies. However, in the study of the effects of Europeanization, the focus is placed on the national executive, the national legislature, national courts, and the relationship between national and subnational levels of government.

Pravni fakultet u Rijeci, 2004, 103.). Non-legislative acts can be delegated and implemented. The power to adopt non-legislative acts (delegated regulations, directives, and decisions) may be delegated exclusively to the European Commission to supplement or amend certain elements of non-key legislative acts (Art. 290 (1) TFEU). In situations requiring a uniform implementation of binding acts of the Union, the Council of the European Union or the European Commission is empowered to adopt implementing acts (implementing regulations, directives, and decisions) (Art. 291 (2) and (4) TFEU).

33 Flavia Jurje, "Europeanization of New Member states: Effects on Domestic Political Structures", in Europeanization Revised: Central and Eastern Europe in the European Union, eds. Michał Matlak, Frank Schimmelfennig, Tomasz P. Woźniakowski, European University Institute, Robert Schuman Centre for Advanced Studies, 2018., 59. 


\section{ADAPTATION OF DOMESTIC STRUCTURES}

The main problem that arises in the study of the phenomenon of Europeanization is the (in)ability to determine a unit of measure which could objectively determine the measure of Europeanization of the Member States. In this regard, Börzel offers a measurement scale with five different responses that the Member States give to adaptation pressures ${ }^{34}$. However, before explaining each of them, it should be noted that it is challenging to define objective criteria by which to accurately distinguish each of the stages on a scale of measurement; in most cases, it is necessary to rely on the "intuition and interpretative skills" of the researchers ${ }^{35}$.

The stages of change range from inertia and retrenchment to absorption, accommodation, and transformation ${ }^{36}$. Inertia implies the absence of change as the Member States resist implementing the adaptation required to meet European requirements. In such cases, the European Commission may institute legal proceedings against the Member States, resulting in a further increase in adaptation pressures. The second stage is the so-called retrenchment, which represents a situation where "resistance to change can have a paradoxical effect in terms of increasing rather than reducing the discrepancy between the European and domestic levels" ${ }^{37}$. Absorption represents a low degree of adaptation whereby the Member States adopt European requirements without substantially altering the existing structures and the logic of political behavior. This might include, for example, revising strategies established to achieve specific

34 Tanja A. Börzel, "Europeanization: How the European Union Interacts with its Member States", in The Member States of European Union, eds. Simon Bulmer, Christian Lequesne, Oxford: Oxford University Press, 2005, 58.

35 Claudio M. Radaelli, Romain Pasquier, "Conceptual Issues”, in Europeanization. New Research Agenda, eds. Paolo Graziano, Maarten P. Vink, Houndmills, Basingstoke: Palgrave Macmillan, 2007, 40.

36 Because no changes in domestic structures occur in the first two cases, some analysts limit the measurement scale to three points: low (absorption), moderate (accommodation), and a high degree of adaptation (transformation).

37 Tanja A. Börzel, "Europeanization: How the European Union Interacts with its Member States", in The Member States of European Union, eds. Simon Bulmer, Christian Lequesne, Oxford: Oxford University Press, 2005, 59. 
goals or minor institutional changes aimed at redesigning how EU-related information becomes a priority area in the legislative process ${ }^{38}$. Accommodation, on the other hand, is an adaptation of the existing processes, institutions, and policies without changing the key features and collective understandings (e.g. by "patching up" new policies and institutions onto existing ones) ${ }^{39}$. It indicates a moderate degree of adaptation. Adaptation pressures are more pronounced in this case. The most common way of accommodating is to "add" new policies and institutions to the existing ones, but without changing the latter. For example, adopting European initiatives to increase the scope of a particular ministry so that the new instruments of public policy coordination can be adopted. Finally, a high degree of adaptation is achieved through the transformation of policy and systemic domestic structures. Transformation can be a complete replacement of the existing with new processes, institutions, and policies, or a fundamental alteration of the existing processes in terms of their key features and/or collective understandings. Ladrech points out that fundamental changes are very rare. They can occur in times of crisis when the EU intervenes in a Member State to a greater extent than it would normally do. In addition, Börzel and Risse believe that transformation can occur if the uploading of domestic preferences results in a proposal for public policies that will facilitate Member States' intentional implementation of fundamental changes ${ }^{40}$.

38 Robert Ladrech, Europeanization and National Politics, The European Union Series: Palgrave Macmillan, 2010, 36.

39 Adrienne Héritier, "Differential Europe: National Administrative Responses to Community Policy”. in Transforming Europe. Europeanization and Domestic Change, eds. Maria Green Cowles, James A. Caporaso, Thomas Risse, Ithaca, NY: Cornell University Press, 2001, 54.

40 Tanja A. Börzel, Thomas Risse, "Europeanization: The Domestic Impact of European Union Politics", in Handbook of European Union, eds. Knud E. Jørgensen, Mark A. Pollack, Ben Rosamond, London: Sage, 2007, 495. 
Table 2: Categorization of adaptations of domestic structures

\begin{tabular}{|l|l|l|}
\hline \multicolumn{1}{|c|}{ CATEGORY } & \multicolumn{1}{|c|}{ FEATURE } & DEGREE OF CHANGE \\
\hline Inertia & Member States resist adaptation & No change \\
\hline Retrenchment & $\begin{array}{l}\text { Resistance to change, which further } \\
\text { increases the discrepancy }\end{array}$ & Increase in discrepancy \\
\hline Absorption & $\begin{array}{l}\text { Adoption of European requirements } \\
\text { without substantial changes in public } \\
\text { policies, practices, and preferences }\end{array}$ & Low \\
\hline Accommodation & $\begin{array}{l}\text { Adaptation of public policies, practices, } \\
\text { and preferences, but without changing } \\
\text { their key features }\end{array}$ & Moderate \\
\hline Transformation & $\begin{array}{l}\text { Fundamental changes to the existing public } \\
\text { policies, practices, and preferences or their } \\
\text { replacement with new ones }\end{array}$ & High \\
\hline
\end{tabular}

Source: adapted from Börzel and Risse $e^{41}$

According to the diversity of systems in the Member States, the degree of EU impact, and the intensity of adaptation pressures on each of them varies. Therefore, there is a common position on the lack of convergence of domestic institutions, policies, and processes in relation to the common European model. However, research has also shown that the EU has not caused any divergence between the Member States, i.e., there has been no deepening of the differences between their institutions and policies. Member States facing similar adaptation pressures, as a rule, have similar responses to these pressures as they learn from each other in this regard.

41 Tanja A. Börzel, Thomas Risse, "Conceptualizing the Domestic Impact of Europe”, in The Politics of Europeanization, eds. Kevin Fetherstone, Claudio M. Radaelli, Oxford: Oxford University Press, 2003, 71. 
Therefore, it is possible to talk about convergence in clusters, i.e., groups into which the Member States are grouped by similarity ${ }^{42}$.

\section{EUROPEANIZATION OF SUBNATIONAL LEVELS}

Over the last thirty years, European countries have undergone significant changes in the relationship between central and subnational governments. In this sense, the impact of Europeanization on states varies with the diversity of their territorial organization and system of local self-government. Changes are visible in a number of limitations, but also new possibilities for action and ways of realizing the influence of subnational units ${ }^{43}$. On the one hand, the EU questions the territoriality defined by the traditional conception of the state. By transferring the political decision-making power from the national to the European level, the central government ceases to

42 Risse, Cowles, and Caporaso highlight several reasons for the convergence partiality. First, the EC Treaty stipulates that the adoption of directives only determines the policy outcome that is to be achieved and leaves the Member States the choice of how to achieve the objectives of the directives. Thus, the process of implementing European legislation is characterized by discretion and flexibility. The principle of mutual recognition, which requires the Member States to adopt the standards of other Member States in order to achieve regional trade, also does not contribute to harmonization and uniformity. This establishes a standard of single conditionality in the sense that products must meet the criteria of only one country. Secondly, Europeanization denotes a continuous interaction between the uniformity of the EU system and the diversity and individualism of each Member State. Although the EU system primarily operates on the assumption of uniformity, i.e., for the standards adopted at the European level to be applied uniformly in all Member States, the diversity that derives from the different historical and cultural traditions of the Member States must also be nurtured. The third reason for partial convergence should be sought in the intervening factors that mediate European demands and the outcome of domestic change. Regardless of the degree of adaptation pressures, each country has different institutions and mediating factors that facilitate or limit the implementation of European policies, which then gives them a national character. (Thomas Risse, Maria G. Cowles, James Caporaso, "Europeanization and Domestic Change: Introduction", in Transforming Europe. Europeanization and Domestic Change, eds. Maria G. Cowles, James Caporaso, Thomas Risse, Ithaca, London: Cornell University Press, 2001, 16.)

43 Hussein Kassim, "The Europeanization of Member State Institutions", in The Member States of European Union, eds. Simon Bulmer, Christian Lequesne, Oxford: Oxford University Press, 2005, 282. 
be the highest authority within its borders. The loosening of the hierarchical relationship between central and subnational authorities has led to a reconfiguration of the territoriality of the Member States. Subnational actors operate in a political system that crosses national borders and enables them to pursue their interests independently of the central government. They can directly communicate with EU institutions and cooperate with the sub-national levels of other Member States. The multilevel nature of EU systems enables them to be involved in public policies beyond national borders, for example, through the Committee of the Regions, the Congress of Local and Regional Authorities, or local authorities' networks. In addition, the paradigmatic activities of local actors are also based on informal contacts and personal networks that are very difficult to monitor and therefore provide additional impetus to local autonomy. This provokes the dominant position of central authorities in the European decision-making process ${ }^{44}$. Schulz emphasizes that, by replacing hierarchical and cooperative governance, participatory management has led to significant changes in the logic of influence in European decision making and the triangulation of relations within the European community ${ }^{45}$.

Europeanization processes, on the other hand, influence the way subnational governments perform their functions. The EU's regional policy and cohesion and structural funds are of paramount importance. The possibility of subnational units receiving funding encouraged their participation in lobbying activities. Some units seek to influence the decision-making process through national governments and others through direct action at the European level, individually or in cooperation with other units ${ }^{46}$. Thus, EU regional policy has increased the opportunities for subnational actors to participate in the policy process. This interaction between the subnational and European levels of government is a fea-

44 Marius Guderjan, "European Integration from a Local Government Perspective Theoretical Considerations", UACES Student Forum Conference, University of Surrey. June 30-July 1 2011, https://www.uaces.org/documents/papers/1140/guderjan.pdf.

45 Claus J. Schulze, "Cities and EU governance: policy-takers or policy-makers?", Regional and Federal Studies 1(2003):140.

46 Hussein Kassim, "The Europeanization of Member State Institutions", in The Member States of European Union, eds. Simon Bulmer, Christian Lequesne, Oxford: Oxford University Press, 2005, 283. 
ture of a multi-level governance system. However, it should be noted that there is noticeable inequality in subnational mobilization, both within and across the Member States ${ }^{47}$. As a rule, the capacity of stronger subnational higher-level units is better represented at the European level. Also, the European Commission intends to ensure the participation of subnational authorities in the design and implementation of national programs, which does not necessarily impact the strengthening of their position vis-à-vis the central government.

Local-level Europeanization also includes a download, upload, and horizontal component. Marshall defines the top-down Europeanization of the local self-government as changes in the policies, actions, preferences, and participants of the local governance system that result from the negotiation and implementation of EU programs ${ }^{48}$. On the other hand, bottom-up Europeanization is the transfer of innovative urban practices to the transnational arena for the purpose of incorporating local initiatives in Pan-European policies and programs. In addition, cities have developed various instruments to simplify the transfer of best practices among themselves, which introduces a horizontal component to the Europeanization process.

In the first case, local authorities, as part of a hierarchically structured state system, implement and enforce European regulation and have no direct influence on the political decision-making process at the EU level ${ }^{49}$. Therefore, the local self-government is not viewed as an active subject but

47 Subnational mobilization can take many forms, institutional and non-institutional. The first group includes the Committee of the Regions, which, as an advisory body to the EU institutions, represents subnational interests and partnerships as part of EU structural policy. The second group consists of collective and individual channels of action at the European level. Collective organizations include organizations such as the Assembly of European Regions (AER), the Council of European Municipalities and Regions (CEMR), the Permanent Conference of Local and Regional Authorities of Europe (CLRAE), the International Union of Local Authorities (IULA), etc., and numerous networks of local and regional authorities. Individuals, however, refer to the direct action of subnational authorities in the European arena.

48 Adam J. Marshall, "Europeanization at the urban level: local actors, institutions and the dynamics of multi-level interaction”, Journal of European Public Policy 4(2005):674.

49 Sbragia and Stalfi elaborate these areas as market-building policies, such as market-building policies, market-correcting policies, market-cushioning policies, and non-market policies, such as asylum. (Alberta Sbragia, Francesco Stalfi, "Key Policies", in The Euro- 
an "affected" object ${ }^{50}$. Three areas governed by European law are relevant to subnational governments: the internal market, environmental law, and cohesion policy ${ }^{51}$. In addition to binding regulation, the European Union is also working through various programs and financial instruments in these areas to achieve as many policy objectives as possible. John identifies several stages of Europeanization of the local self-government that he schematically depicts with a ladder. The degrees of Europeanization range from the lowest step that represents absorption in terms of top-down Europeanization to the highest at which European ideas and practices are incorporated into the local policy agenda.

Figure 1: Adaptation levels of local units of government

\begin{tabular}{|c|c|c|c|c|}
\hline \multirow{9}{*}{ 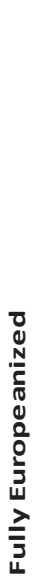 } & & & & $\begin{array}{l}\text { Making council's policies more } \\
\text { "European" }\end{array}$ \\
\hline & & & & $\begin{array}{l}\text { Advising European institutions on } \\
\text { implementation issues }\end{array}$ \\
\hline & \multirow{7}{*}{ 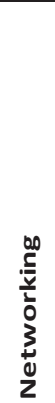 } & & & $\begin{array}{l}\text { Participating and cooperating in } \\
\text { joint projects }\end{array}$ \\
\hline & & & & Transnational networking \\
\hline & & \multirow{5}{*}{ 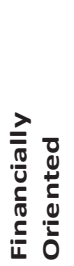 } & & Facilitating economic regeneration \\
\hline & & & & Maximizing EU grants \\
\hline & & & \multirow{3}{*}{ 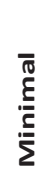 } & $\begin{array}{l}\text { Communicating with public and } \\
\text { private sector }\end{array}$ \\
\hline & & & & Managing European information \\
\hline & & & & Responding to hard law \\
\hline
\end{tabular}

Source: Peter John, Local Governance in Western Europe, London: Sage Publication Ltd., 2001, 72.

pean Union: How does it work?, eds. Elizabeth Bomberg, John Peterson, Alexander Stubbs, Oxford: Oxford University Press, 2008, 117.)

50 Claus J. Schulze, "Cities and EU governance: policy-takers or policy-makers?", Regional and Federal Studies 1(2003):131.

51 Mike Goldsmith, "Variable geometry, multi-level governance: European integration and subnational government in the new millennium", in The Politics of Europeanization, eds. Kevin Fetherstone, Claudio M. Radaelli, Oxford: Oxford University Press, 2003, 120. 
Local levels of governance respond to top-down Europeanization by bridging national borders and making an impact in the European political arena. They seek to achieve their goals by lobbying EU institutions (in particular the Committee of the Regions) and the Council of Europe, creating thereby a direct link between subnational and supranational levels of governance. The emergence of "foreign policy," predominantly cities, and the involvement of local actors in transnational spaces opens up a number of new opportunities for their action ${ }^{52}$.

Finally, Europeanization of local self-government can also occur without the involvement of the European institutions or with their minimal, coordinating role in the process (e.g., the role of the European Commission in funding projects). This refers to collaboration, sharing of experiences, and best practices and finding innovative solutions through transnational networks of local units ${ }^{33}$. These include a broad range of concepts such as lesson drawing ${ }^{54}$, policy transfer ${ }^{55}$, and policy convergence ${ }^{56}$. Twinning between local units and the formation of transnational networks of local governance form a new dimension of the emergence of "foreign policy" and the paradigm of European cities ${ }^{57}$.

52 Hubert Heinelt, Stefan Niederhafner, "Cities and Organized Interest Intermediation in the EU Multi-level System", in Diskurs und Governance - Abschlussbericht der Forschungsabteilung "Zivilgesellschaft und transnationale Netzwerke“, ed. Wolfgang van den Daele, Discussion Paper SP IV 2005-103, Wissenschaftszentrum Berlin für Sozialforschung, 2005, 77.

53 Marius Guderjan, "Local Government and European integration - beyond Europeanisation?”, Political Perspectives, 1(2012):108, http://www.politicalperspectives.org.uk/ wp-content/uploads/PP_6-1_Europeanisation-or-integration-of-local-government-6.pdf.

54 Richard Rose, Learning from Comparative Public Policy, London-New York: Routledge, 2005, 80.

55 Mark Evans, "Understanding Policy Transfer", in Policy Transfer in Global Perspective, ed. Mark Evans, Aldershot-Burlington: Ashgate, 2004, 11.

56 Katharina Holzinger, Christoph Knill, "Causes and conditions of cross-national policy convergence”, Journal of European Public Policy, 5(2005):780.

57 Stephane Paquin, "Paradiplomacy", in Global Diplomacy. An Introduction to Theory and Practice, eds. Thierry Balzacq, Frederic Charillon, Frederic Ramel, translated by William Snow, Paris: Palgrave Macmillan, 2019, 55. The concept of paradiplomacy refers to the international activities of subnational governments beyond the control of their central governments. They open trade and cultural missions abroad, sign treaties and agreements with transregional and transnational local authorities and non-state actors, they participate 


\subsection{Dimensions of Europeanization of subnational levels}

In the analysis of the process dimension (politics), attention is most often focused on political parties and interest groups. With regards to political parties, the EU has no direct jurisdiction over their organization and activities, nor is there direct funding from European funds that would motivate them to invest their own organizational resources in redirecting action to the European level. Although the members of political parties are elected to the European Parliament, their activities remain primarily related to the domestic political arena, i.e., the executive and the representative body. The Europeanization of political parties can be discussed if there is a change in their program, organization, party competition, and integration with European actors, considering that the motive for change is not exclusively of a "domestic" nature ${ }^{58}$. Research on party programs has shown a moderate increase in references to the $\mathrm{EU}$ and a slightly weaker reference to specific policy proposals. However, most programs, as a rule, contain a chapter expressing the views of the party on the position of their country as an EU Member State.

One consequence of Europeanization on the organizational structure of political parties is an increase in the degree of leadership autonomy. A moderate increase in the number of intra-party positions dealing with EU issues can also be observed. Most often, in this respect, these are sections for international activities. There are more opportunities for participation of the party apparatus at the European level: (1) infiltrating Members of the European Parliament into the governing bodies of the party, (2) involving party representatives in transnational party federations, (3) involving representatives of sections for international activities at the European and world level, or (4) drafting party manifests and other policy documents for the European Parliamentary elections. Furthermore, possible changes in party competition may be caused by the emergence of

in international networks of local units and they "sometimes even challenge the official foreign policy of their central governments through their statements or actions" (Alexander S. Kuznetsov, Theory and Practice of Paradiplomacy. Subnational governments in international affairs, London, New York: Routledge, 2016, 3).

58 Robert Ladrech, "Europeanization and Political Parties: Towards a Framework for Analysis", Party Politics, 4(2002):396. 
Eurosceptic or anti-European political parties. Whether they will influence and evoke change depends on the number of votes, i.e., the confidence that will be shown toward them in the elections. Finally, the Europeanization process encourages the establishment of relationships and the involvement of domestic parties in transnational federations of parties operating at the European level ${ }^{59}$.

Unlike political parties, interest groups do not have the primary goal of seizing power, although they support a particular party that represents their interests. Also, interest groups do not restrict their activities solely to the national political system, as do political parties. In addition to the national arena, they can be activated at the European level if they consider it an appropriate political structure to achieve their goals. The European Commission calls on domestic interest groups to contribute to the creation of European public policies by providing information and commenting on the proposed legislation. Whether its focus will be at the European level depends on the cost-effectiveness of such engagement at the national level, as determined by a cost-benefit analysis. Therefore, the Europeanization of interest groups is considered to be present if their activities are shifted to the supranational level or changes in the strategy of action in the domestic arena. The EU system of multilevel governance is a key factor in

59 John McCormick, Understanding the European Union: A Concise Introduction, The European Union Series: Palgrave Macmillan, 2011, 132. According to Mair, the impact of Europeanization on political parties and electoral systems can be direct and indirect. In both cases, it can be a process of institutionalizing a particular European political system and/or the penetration of European rules, directives, and norms into the domestic sphere. The direct effect of institutionalization is evident in the creation and consolidation of trans-European party alliances and coalitions, while the direct effect of penetration may be the emergence of new anti-European political parties or anti-European inclinations within the existing parties. On the other hand, indirect, non-partisan channels of representation (interest groups, civil society organizations) and the "enlargement of 'Europe' in domestic discourse" appear as indirect effects of institutionalization (Peter Mair, "Political Parties and Party Systems", in Europeanization. New Research Agenda, eds. Paolo Graziano, Maarten P. Vink, Houndmills, Basingstoke: Palgrave Macmillan, 2007, 157.) Penetration, in turn, is indirectly affected by the weakening of national party competition due to the constraints of national decision-making and the transfer of powers to the European one. 
motivating national interest groups to create associations at the European level and/or to lobby EU institutions directly ${ }^{60}$.

In examining the impact of Europeanization on domestic public policies, attention must be paid to distinguishing the downloading process of European regulations that domestic structures, including subnational authorities, are required to implement in the national legal system from the effects of such implementation on domestic public policies, including local ones. In the first case, for example, the measure of coherence between European and domestic public policies and the variation in the degree of coherence between different countries can be explored. Also, when it comes to the effects or consequences on public policies, the research focuses on finding, for example, new organizational forms designed to implement EU policies, identifying changes in existing national policies, or brand-new policy dimensions that have not existed so far in the domestic system ${ }^{61}$.

The dimension of political institutions, among other things, involves a change in the relationship between national and subnational levels of government. The Europeanization process has opened new possibilities for action and channels of influence to subnational authorities. One consequence of the redefinition of Member States' statehood is the activation of subnational actors within a broader political system that crosses national borders and within which they can develop and pursue projects independently of domestic capital. EU regional policies, the activities of the Committee of the Regions and the Congress of Local and Regional Authorities of the Council of Europe, and the activities of networks of local and regional authorities at the European level are mechanisms of Europeanization that allow subnational levels to promote their interests and influence public policy making.

60 Robert Ladrech, "The Europeanization of Interest Groups and Political Parties", in The Member States of European Union, eds. Simon Bulmer, Christian Lequesne, Oxford: Oxford University Press, 2005, 323.

${ }^{61}$ Robert Ladrech, Europeanization and National Politics, The European Union Series: Palgrave Macmillan, 2010, 11. 


\subsection{Mechanisms of Europeanization of subnational levels}

Finally, it is necessary to analyze the main mechanisms, i.e., actors of the Europeanization of subnational levels of government. The purpose of the analysis is to identify the ways and possibilities of involving local units in the European integration process as well as to create European public policies. In addition to the influence of the European Union, activities of the Council of Europe and networks and associations of local and regional units promoting their interests and participation in European governance are crucial.

The European Union has no exclusive competence to regulate local self-government. Therefore, EU primary and secondary legislation does not systematically regulate this area but rather with specific provisions. Such provisions are found in acts that regulate other areas and policies within those areas that may be significant for subnational authorities. On the other hand, EU institutions have adopted a number of soft-law instruments, such as communications, resolutions, and opinions that address various local government topics but produce no legal but rather practical effects.

In addition to the regulations, the EU influences subnational levels through regional policy and the activities of the Committee of the Regions and the Office for Development and Cooperation. The European Commission contributes to the regional and local development of the Member States. Specifically, a Directorate-General for Regional Policy is set up within the Commission, whose mission is to strengthen the economic, social, and territorial cohesion of the regions and countries of the European Union $^{62}$. Reducing the level of development gap is achieved by investing

62 Territorial cohesion becomes the third dimension of cohesion policy with the entry into force of the Treaty of Lisbon (Protocol 28) and the introduction of the Europe 2020 strategy. The concept of territorial cohesion builds links between economic efficiency, social cohesion, and environmental balance, putting the sustainable development of different territories at the heart of public policy making. (European Commission, Territorial Cohesion. Turning territorial diversity into strength. A Green Paper. COM (2008) 616 final, 06.10.2008.) The main goals are to achieve integrated development of national territories, to formulate public policies tailored to local needs, and to foster cooperation between national territories in order to strengthen European integration. 
in infrastructure projects, building an information society, education, and innovation, sustainable development, developing new products and production methods, energy efficiency, etc. and encouraging cross-border cooperation. In doing so, it helps less prosperous countries or those facing structural problems of improving competitiveness and achieving a higher rate of economic development in a sustainable way. One of the EU goals is to design an efficient and effective structural policy that will benefit European citizens and directly contribute to creating the conditions for successful enlargement of the European Union in accordance with the principle of sound financial management ${ }^{63}$. Regional policy is an investment policy, and its fundamental principle is financial solidarity, which is reflected in the channeling of funds through the Structural Funds. It encourages job creation, competitiveness, economic growth, and improving the quality of life.

The Committee of the Regions represents the local and regional interests of the Member States in the process of shaping EU policies and legislation. The Treaty of Lisbon reinforced the Committee's position, underlining the commitment of EU institutions to consult it on new proposals in areas that have an impact on regional and local governance. In addition to working with institutions daily, it maintains contacts with all other stakeholders representing local and regional units and civil society ${ }^{64}$.

63 Ian Bache, "Cohesion Policy", in Europeanization. New Research Agenda, eds. Paolo Graziano, Maarten P. Vink, Houndmills, Basingstoke: Palgrave Macmillan, 2007, 244.

${ }^{64}$ The Committee of the Regions maintains relations with various stakeholders through a consultation process and structural dialogue. The consultations aim to establish contacts between the rapporteurs of each committee and representatives of different stakeholder groups, such as associations of local and regional authorities and local and regional public services. Stakeholders present their views for which rapporteurs will decide whether to consider them when drafting an opinion. Structural dialogue, on the other hand, is a new form of contact that applies in addition to existing methods of public and institutional consultation with EU institutions and whose nature is necessarily political. The purpose of the structural dialogue is to improve EU legislation, taking into account the views of local and regional associations before the formal decision-making process begins, i.e., in the pre-legislative phase. Structural dialogue also seeks to ensure a better understanding of policy guidelines, to make the functioning of the EU system more transparent and meaningful to citizens, and to strengthen policy coordination between the European Commission and local or regional authorities. The idea of structural dialogue stems from the White Paper on European Governance, which emphasized the need to strengthen the cooperation 
In the area of the European Union's external relations, the Office of Development and Cooperation was set up in 2011, whose mission is to contribute to the creation of the Union's development policy and to assist countries in need through various programs and projects. The organizational unit D2, which is responsible for cooperation with local authorities, operates within Directorate D. The specificity in the work of this unit is conducting a structural dialogue with the representatives of civil society organizations and local authorities of the EU Member States and partner countries. The objective of the Structural Dialogue initiative is to increase the effectiveness of involving all stakeholders in the process of shaping European development policies and programs. It is, in fact, the European Commission's initiative to respond to the conclusions of several reports on the evaluations of civil society organizations and the Court of Auditors, as well as the requests made by the European Parliament, local authorities, and civil society at the Accra Development Assistance Forum ${ }^{65}$. It had a goal to reach a mutual understanding and agree-

of EU institutions with representatives of European regions and cities. Accordingly, the European Commission has adopted a "Communication on Dialogue with Associations of Regional and Local Authorities on the Formulation of EU Policy," which emphasizes the lasting character and involvement of the Committee of the Regions in the political decision-making process. (Communication from the Commission, 2003. Dialogue with associations of regional and local authorities on the formulation of European Union policy, COM (2003) 0811 final, 19.12.2003.) The dialogue can be general or thematic. In the first case, he or she meets with the President of the European Commission on issues of broader interest, such as the EC's annual work program. Thematic dialogue, however, is conducted with an individual EC member and focuses on a specific policy area, such as communication policy, education, energy, etc.

65 The 2008 Ghana Forum adopted an Action Plan which states that three challenges need to be addressed in order to enhance development cooperation: (1) governments of developing countries should, together with Parliament and citizens, be involved in the formulation of development policies and take the lead in managing their implementation, (2) integrate all stakeholders in development policies into effective and inclusive partnerships, and (3) achieve as many development outcomes as possible, with the assurance that Member State Ministers will be responsible for them. Also, the Forum launched the International Aid Transparency Initiative (IATI), which seeks to facilitate access to, and interpretation and use of, aid spending information. (Accra Agenda for Action, http:// siteresources.worldbank.org/ACCRAEXT/Resources/4700790-1217425866038/AAA-4SEPTEMBER-FINAL-16h00.pdf, 30. 10. 2019.) 
ment on the main challenges facing civil society and local authorities, find ways to improve and strengthen their partnership with them and explore ways to better adapt them to European policies. Unit D2 acts as a single point of contact for providing information to civil society organizations and local authorities, as well as distributing their inquiries to the relevant services. It is also responsible for developing and promoting development policy education and raising public awareness of development issues. To that end, it is responsible for the formulation of multi-annual programs and the management of the Non-State Actors and Local Authorities in Development program ${ }^{66}$.

In the early 1990s, the Council of Europe began implementing assistance and cooperation programs to develop democratic stability, i.e., to strengthen the democratic institutions of its Member States. In the area of local democracy, the programs were inspired by the European Charter of Local Self-Government and prepared in accordance with the needs expressed by national authorities. The programs are funded from the Council of Europe budget and by means of European Commission support and voluntary contributions from individual Council members to specific projects. Three core strategic objectives of the program are related to the implementation of the subsidiarity principle in the legal order of the Member States: (1) fostering the process of decentralization, (2) supporting the development of effective local and regional self-government, and (3) entrenching democracy at the local and regional level. The approach to reforming local government systems is characterized by the involvement of all potential stakeholders and the preparation of national plans for decentralization. In addition to the proposed legislation and institutional changes, capacity-building programs are being formulated, enabling an integrative reform of local self-government ${ }^{67}$. The Council of Europe seeks the involvement of local and regional authorities in the integration process through the activities of the Congress of Local and

66 European Commission, 2012. Main missions of DEVCO Directorates \& Units. 21.12.2012.

67 The Council of Europe's fundamental regulatory documents are international treaties (conventions, framework conventions, protocols, charters, and agreements. In addition, a number of recommendations, resolutions, and opinions have been adopted in the field of local governance. 
Regional Authorities, the Center of Expertise for Good Governance, the European Committee on Democracy and Governance, and specialized ministerial conferences.

The Congress of Local and Regional Authorities, as an advisory body to the Council of Europe, has the role of promoting local and regional democracy, improving local and regional governance, supporting the process of devolution and regionalization, and cross-border cooperation between cities and regions. To this end, it adopted a number of recommendations, resolutions, and opinions. Within the Congress, there is a Committee of Local Authorities whose work is mainly focused on monitoring local democracy in the Member States, observing local elections, and supporting initiatives promoting cohesion in European cities. However, it is also responsible for civic participation, intercultural dialogue, e-democracy, and respect for equality and diversity. The Committee discusses these issues and prepares draft recommendations and resolutions for submission to the Congress.

The Center of Expertise for Good Governance works closely with Congress. It is the Council of Europe's executive body in the field of multilevel governance, which supports central, regional, and local authorities in improving their regulations, institutional capacity and efficiency in providing services, and exercising public authority. Through its activities, the Center seeks to demonstrate to the Member States the importance of the decentralization process and the strengthening of the capacity and role of local authorities. To this end, it offers, in line with good practices in the European Union, a range of practical programs and instruments in different fields: performance management, citizen participation, education and training, and exchange of experience. Currently, 32 programs are implemented in twenty countries in Europe ${ }^{68}$. In addition to legal aid programs, an important initiative of the Center is the Strategy for Innovation and Good Governance at the local level, which was adopted by the Valencia Declaration of 2007.

The strategy is based on the lessons and experiences of the Member States and their cooperation within the Council of Europe and contains

68 Centre of Expertise for Good Governance, https://www.coe.int/en/web/good-governance/centre-of-expertise, 25.09.2019. 
twelve principles of good democratic governance that guide public bodies in improving the quality of local governance: (1) fair conduct of the electoral process, representative and participatory democracy, (2) responsiveness of local authorities, (3) efficiency and effectiveness of resource utilization, (4) openness and transparency of local government work, (5) rule of law, (6) ethical conduct, (7) competence and capacity, (8) innovation and openness to change, (9) sustainability and long-term orientation, (10) sound financial management, and (12) accountability. Considering the fact that the local level is closest to the citizens and provides them with essential public services, it is of utmost importance to adopt the principles of good local governance. Therefore, national and regional authorities and associations of local authorities are urged to commit themselves, in accordance with their respective competences and powers, to the pursuit of democratic governance. Developing an action program for this purpose is an expression of public commitment to improving the quality of management and operation of public services ${ }^{69}$.

The Council of Europe also operates a European Committee on Democracy and Governance, which has four main areas of activity ${ }^{70}$. The first area concerns democratic participation and public ethics. Since the effectiveness of democracy depends on the possibility of citizen participation in governance, it seeks to facilitate the exercise of that right and increase its role in political decision making and resolution of local issues. To achieve this, measures such as increasing transparency, e-governance, good communication, promoting youth participation, increasing the availability of local political information, etc. are used. The second area covers the institutional structure and legal framework. Local authorities are a key element of the European political system as they provide numerous services and are major players in developing the social and economic well-being of citizens. The Committee examines issues related to the legal and institutional framework of local governance, the structure of local authorities and action in different Member States, and finds ways to strengthen, harmo-

69 European Committee on Local and Regional Democracy, 2007. The Valencia Declaration. MCL-15 (2007) 5 final, 16.10.2007.

70 Depending on the area, tasks are performed by the subcommittees on finance and public services (LR-FS), good governance (LR-GG), and institutions and cooperation (LR-IC). 
nize, and improve the system of local self-government. For example, efforts are being made to address the difficulties that state authorities encounter when carrying out territorial reforms, or to engage in an institutional dialogue between different levels of governance on issues of common interest or competence. Within the third area, local finance and public services, the European Committee on Local and Regional Democracy seek to secure sufficient financial resources to carry out local affairs so that local and regional authorities can provide citizens with a better and more efficient service. This can be achieved if the authorities have a high degree of autonomy in managing their own finances, if they act transparently, and show a high degree of responsibility. Finally, the fourth area involves cross-border cooperation. In this respect, confidence-building measures are promoted to enhance good neighborly relations and tolerance; cross-border bodies are established to maintain and enhance cross-border relations and increase the efficiency and effectiveness of public services through shared facilities and services.

One of the Council of Europe's methods of work is the holding of specialized ministerial conferences, including those of ministers responsible for local and regional self-government, which is held every two years in order to discuss current local governance topics and define actions to be taken in the coming period. From 2005 to 2015, four conferences were held to adopt the Declaration on Delivering Good Local and Regional Governance (Budapest Declaration, 2005), the Declaration on the Strategy for Innovative and Good Governance at Local Level (Valencia Declaration, 2007), the Declaration on Good Local and Regional Governance in times of crisis (Utrecht Declaration, 2009), and the Declaration on Local Government in Critical Times: Policies for Crisis, Recovery and a Sustainable Future (Kyiv Declaration, 2015) . $^{71}$

Finally, the activities of transnational networks bringing together European local and regional units are also significant. The most active are the Network of Associations of Local Authorities of South-East Europe, the Council of European Municipalities and Regions, EUROCITIES, the Eu-

71 Council of Europe, https://www.publicsearch.coe.int/\#k=ministerial\%20conference $\# \mathrm{f}=\% 5 \mathrm{~B} \% 5 \mathrm{D}, 26.09 .2019$. According to the current list of ministerial conferences, this is no longer foreseen. 
ropean Federation Local Authority Chief Executive Officer, and the European Association for Local Democracy.

The Network of Associations of Local Authorities of South-East Europe (NALAS) was established in 2001 and today brings together 20 associations. In order to bring local governance closer to European standards in Southeast European countries, NALAS has the status of an observer in the European Committee of the Regions and the Council of Europe, and maintains business cooperation with the Forum for Economic and Sustainable Development of Europe (FEDRE), the Council of European Municipalities and Regions (CEMR), Austrian cities and regions, the Council of Europe, etc. The Network's activities are implemented through several working groups of experts responsible for association development, energy efficiency, fiscal decentralization, solid waste and water management, urban planning, and sustainable tourism. In addition, the Network provides several services to its members: (1) Quick Response service, specialized in regional ad hoc information collection and analysis, used by member Associations in dealing with important policy issues or otherwise negotiating with their respective central governments; (2) Shadowing Program, as a mechanism for permanent exchange and transfer of knowledge between members, through coaching, mentoring, and on-job learning using the expertise within the NALAS network; (3) Peer Review, as a service designed to promote the process of learning from the experience of other NALAS members on the topic of importance for the member that requests the service (Host Association); (4) E-academy, i.e., lectures on topics such as local finance management, disaster risk management, equality for local people, and others are offered; and (5) the tools that challenge some of the local management segments: cost and finance model for solid waste management, water asset management, and solid waste management information system.

The Council of European Municipalities and Regions (CEMR) was founded in 1951 and today counts 60 national associations of cities, municipalities, and regions with around 130,000 local and regional authorities represented. In order to foster an exchange of experiences and good practice, the Council organizes seminars, focus groups, and conferences on a broad range of topics (governance, environment, international engagement, local public services management, etc.). Particularly important 
twinning projects are connecting cities from across Europe. In this regard, the Council closely cooperates with the Directorate-General of the European Commission responsible for education and culture.

EUROCITIES is a network of major European cities that brings together more than 140 major cities in over 39 countries. Within the Network, forums for culture, economy, environment, knowledge society, mobility, social issues, and cooperation have been established. The main priority is to support the inclusion of cities in the process of shaping and implementing public policies, which is hoped to be achieved by strengthening the position of the Network as a partner of EU institutions and national governments. To accomplish these goals, the Network performs several key activities: (1) projects in areas such as culture, the environment, knowledge society, mobility, etc., with the aim of creating public policies and exchanging experiences among its members; (2) organizing workshops, forums, and conferences, and (3) publishing publications on policy priorities and measures for their implementation at the local level as well as case studies on individual members.

The European Federation Local Authority Chief Executive Officer (UDiTE) is a professional association that brings together about 15,000 members of national associations of 14 local governments. Primarily, exchange and internship programs of local managers are being developed between local European units because such experience is invaluable for the professional development of the individual and is the most effective way of transferring knowledge and good practice as well as building strong links between European countries. In this project, the Federation works closely with the Committee of the Regions and the EU Commission.

The European Association for Local Democracy (ALDA) has more than 300 members from over 40 countries. It primarily promotes good governance and civic participation at the local level (facilitating co-operation between local authorities and civil society), but also in the creation of European policies. It has the status of an observer in the Regional Council and Congress of Local and Regional Authorities of the Council of Europe, and is linked to organizations such as the European Confederation of Non-Governmental Organizations for Reconstruction and Development, the World Alliance for Citizen Participation, the European Movement In- 
ternational, the Conference of International Non-Governmental Organizations, the Central and Eastern Europe Citizens Network, and others. It conducts its activities through various forms of action: co-ordination of 14 local democracy agencies, conducting their own projects, and supporting various initiatives of local stakeholders by providing them with the necessary experts.

\section{CONLUSION}

Opportunities for local authorities to participate in governance processes at the European level are increasing in parallel with the strengthening of the European integration process, which results in the loosening of territorial political ties and the allocation of regulatory powers between different institutional levels. Thus, the Europeanization process increases the number of relevant international actors, strengthens international cooperation, and the cross-border learning process. The increasing intersection of national political systems and national and international policies has led to the emergence of multi-level governance in Europe, in which local authorities are seen as partners in policy processes. This means that, in addition to the implementation of European standards (downloading), they have the ability to upload their own preferences to the supranational level.

Although the central, primarily, the executive branch, it is still considered the "gatekeeper" of the European institutions, several factors contribute to strengthening the position of subnational levels of government in the European environment. These are various mechanisms of Europeanization of local self-government, such as EU regional policy, the opening of representative offices of local units in Brussels, the activities of the Committee of the Regions and the Congress of Local and Regional Authorities, the activities of European networks and associations of local authorities, etc. With the entry into force of the Lisbon Treaty 2009, the role of local self-government was further strengthened by explicitly prescribing the application of the principle of subsidiarity to the exercise of European Union competences (TEU, Art. 5 (1)). In addition, Protocol no. 2 on the application of the principle of subsidiarity and proportion- 
ality at all stages of the legislative procedure forms an essential part of the Lisbon Treaty.

Europeanization processes have stimulated reorganization and changes in the structure of local units, as well as the implementation of a strategic and participatory approach to governance. Intra-organizational structural changes include the creation of a special organizational unit (department, office, service) or the creation of a new position of an advisor (associate) in charge of European integration affairs. Also, in order to better prepare local units for the use of European funds, they need to accept the challenge of strategic planning for development projects ${ }^{72}$. Such an approach to development requires an adaptation to the requirements imposed by the Europeanization (and globalization) processes. Specifically, in the context of local development planning, the European Union promotes the principle of partnership, i.e., the joint action of territorially and sectorally different actors. In this case, the principle of partnership also implies the participation of all who can find their interest in developing and implementing a development strategy ${ }^{73}$.

It is possible to distinguish between horizontal and vertical participation. The first form assumes the participation of different sectors, social groups, manufacturers, companies, etc., while vertical participation refers to the hierarchy between national and local authorities in the decision-making process. Thus, the actors in the participatory process can be representatives of local and central government, local population, civil society organizations, the private sector, scientific institutions, sponsors, etc. Finally, local development agencies whose key activities are to achieve so-

72 Development projects contain strategic goals and priorities for achieving them. The priorities are specified by strategic measures, which determine the institutions responsible for the implementation of the project, the estimated implementation period, the expected costs and sources of funding, the monitoring of implementation, the final beneficiaries, and the final benefits.

73 In contrast to the participatory approach, whose main feature is citizen involvement in planning, the traditional approach consists of engaging external stakeholders (experts): international organizations, networks, individual entrepreneurs, governments of other countries, etc. (Paul Stubbs, "Participacija, partnerstvo i/ili pomoć: unutarnji i vanjski dionici u održivom razvoju”, in Participativno upravljanje za održivi razvoj, ed. Željka Kordej-De Villa, Zagreb: Ekonomski institut Zagreb, 2009, 155-156.) 
cial consensus on development strategy and its development, encouraging networking and cooperation of local units, local businesses, and citizens. The ultimate goal of their activities is to create an attractive environment for investors and trade.

\section{REFERENCES}

Accra Agenda for Action, http://siteresources.worldbank.org/ACCRAEXT/Resources/4700790-1217425866038/AAA-4-SEPTEMBER-FINAL-16h00.pdf.

Bache, Ian. "Cohesion Policy". In Europeanization. New Research Agenda, edited by Paolo Graziano, Maarten P. Vink, 239-252. Houndmills, Basingstoke: Palgrave Macmillan, 2007.

Bomberg, Elizabeth, John Peterson. "Policy Transfer and Europeanization: Passing the Heineken Test?". Queen's Papers on Europeanisation 2000, 2:1-15, http://www.qub.ac.uk/schools/SchoolofPoliticsInternationalStudiesandPhilos ophy/FileStore/EuropeanisationFiles/Filetoupload,38445,en.pdf.

Božić, Saša. "Nacionalizam-nacija, „,transnacionalizam“",„transnacija“: mogućnosti terminološkog usklađivanja”. Revija za sociologiju 2004, 3-4:187-203.

Bruter, Michael. Citizens of Europe? The Emergence of a Mass European Identity. Houndmills. Basingstoke: Palgrave Macmillan, 2005.

Börzel, Tanja A. "Shaping and Taking EU Policies: Member State Responses to Europeanization". Queen's Papers on Europeanisation 2003, 2:1-15. http:// citeseerx.ist.psu.edu/viewdoc/download?doi=10.1.1.535.1021\&rep=rep1\&type $=$ pdf.

Börzel, Tanja A. "Europeanization: How the European Union Interacts with its Member States". In The Member States of European Union, edited by. Simon Bulmer, Christian Lequesne, 45-70. Oxford: Oxford University Press, 2005. Börzel, Tanja A., Diana Panke. "Europeanization". In European Union politics, edited by Michelle Cini, Nives Perez-Solorzano Borragan, 405-417. Oxford: Oxford University Press, 2010.

Börzel, Tanja A., Thomas Risse. "Conceptualizing the Domestic Impact of Europe". In The Politics of Europeanization, edited by Kevin Fetherstone, Claudio M. Radaelli, 57-82. Oxford: Oxford University Press, 2003.

Börzel, Tanja A., Thomas Risse, "Europeanization: The Domestic Impact of European Union Politics". In Handbook of European Union, edited by Knud E. Jørgensen, Mark A. Pollack, Ben Rosamond, 483-504. London: Sage, 2007. 
Bruszt, Laszlo, Visnja Vukov. "Making states for the single market: European integration and the reshaping of economic states in the Southern and Eastern peripheries of Europe". West European Politics 2017, 4:663-687.

Caporaso, James A., Min-hyung Kim. "The dual nature of European identity: subjective awareness and coherence". Journal of European Public Policy 2008, 16:19-42.

Cardona Peretó, Francisco Anke Freibert. "The European Administrative Space and SIGMA Assessments of EU Candidate Countries". Hrvatska javna uprava 2007, 1:51-59.

Centre of Expertise for Good Governance, https://www.coe.int/en/web/good-governance/centre-of-expertise, 25.09.2019.

Commission of European Communities: European Governance. A White Paper. Brussels 25. 7. 2001. COM (2001) 428 final.

Council of Europe, https://www.publicsearch.coe.int/\#k=ministerial\%20conference\#f $=\% 5 B \% 5 D, 26.09 .2017$.

Crouch, Graeme. "New Ways of Influence: 'Horizontal Europeanization in Southeast Europe". In Europeanization Revised: Central and Eastern Europe in the European Union. edited by Michał Matlak, Frank Schimmelfennig, Tomasz P. Woźniakowski, 38-54. European University Institute, Robert Schuman Centre for Advanced Studies, 2018.

European Commission. 2008. Territorial Cohesion. Turning territorial diversity into strength. A Green Paper. COM (2008) 616 final, 06.10.2008.

European Commission. 2012. Main missions of DEVCO Directorates \& Units. 21.12.2012.

European Committee on Local and Regional Democracy. 2007. The Valencia Declaration. MCL-15 (2007) 5 final, 16.10.2007.

European Union. 2007. Treaty of Lisbon. OJ C 306, 17. 12. 2007.

Evans, Mark. "Understanding Policy Transfer". In Policy Transfer in Global Perspective, edited by Mark Evans, 10-44. Aldershot-Burlington: Ashgate, 2004.

Featherstone, Kevin, George Kazamias. "Introduction: Southern Europe and the Process of 'Europeanization"'. South European Society and Politics 2000, 2:1-22, https://www.tandfonline.com/doi/pdf/10.1080/13608740508539600?needAccess=true.

Goldsmith, Mike. "Variable geometry, multi-level governance: European integration and subnational government in the new millennium". In The Politics of Europeanization, edited by Kevin Fetherstone, Claudio M. Radaelli, 112-133. Oxford: Oxford University Press, 2003.

Guderjan, Marius. "European Integration from a Local Government Perspective Theoretical Considerations". UACES Student Forum Conference, Univer- 
sity of Surrey. June 30-July 1 2011, https://www.uaces.org/documents/papers/1140/guderjan.pdf.

Guderjan, Marius. "Local Government and European integration - beyond Europeanisation?". Political Perspectives 2012, 6:105-128, http://www.politicalperspectives.org.uk/wp-content/uploads/PP_6-1_Europeanisation-or-integration-of-local-government-6.pdf.

Harmsen, Robert. "Europeanization and Governance: A New Institutionalist Perspective". In Europeanization, Institutions, Identities and Citizenship, edsited by Robert Harmsen, Thomas M. Wilson, 51-81. Amsterdam-Atlanta: Rodopi, 2000.

Harmsen, Robert, Thomas M. Wilson. "Introduction: Approches to Europeanization". In Europeanization, Institutions, Identities and Citizenship, edited by Robert Harmsen, Thomas M. Wilson, 13-26. Amsterdam-Atlanta: Rodopi, 2000.

Hartley, Trevor C. Temelji prava Europske zajednice. Rijeka: Pravni fakultet u Rijeci, 2004.

Heinelt, Hubert, Stefan Niederhafner. "Cities and Organized Interest Intermediation in the EU Multi-level System". In Diskurs und Governance - Abschlussbericht der Forschungsabteilung "Zivilgesellschaft und transnationale Netzwerke", edited by Wolfgang van den Daele, Discussion Paper SP IV 2005-103, 76-88. Wissenschaftszentrum Berlin für Sozialforschung, 2005.

Héritier, Adrienne. "Differential Europe: National Administrative Responses to Community Policy". In Transforming Europe. Europeanization and Domestic Change, edited by Maria Green Cowles, James A. Caporaso, Thomas Risse, 44-59, Ithaca, NY: Cornell University Press, 2001.

Hermann, Richard K., Thomas Risse, Marilyn B. Brewer. Transnational Identities: Becoming European in the EU. Oxford: Rowman \& Littlefield, 2004.

Holzinger, Katharina, Christoph Knill. "Causes and conditions of cross-national policy convergence”. Journal of European Public Policy 2005, 12:775-796.

Howell, Kerry E. „Developing Conceptualisations of Europeanization: Synthesising MethodologicalApproaches“. Queen's PapersonEuropeanisation 20043:1-13.http:// citeseerx.ist.psu.edu/viewdoc/download?doi=10.1.1.496.9117\&rep=rep1\&type $=$ pdf.

John, Peter. Local Governance in Western Europe. London: Sage Publications Ltd., 2001. Jurje, Flavia. "Europeanization of New Member states: Effects on Domestic Political Structures". In Europeanization Revised: Central and Eastern Europe in the European Union, edited by Michał Matlak, Frank Schimmelfennig, Tomasz P. Woźniakowski, 55-71. European University Institute, Robert Schuman Centre for Advanced Studies, 2018. 
Kassim, Hussein. "The Europeanization of Member State Institutions". In The Member States of European Union, edited by Simon Bulmer, Christian Lequesne, 279-312. Oxford: Oxford University Press, 2005.

Knill, Christoph, Dirk Lehmkuhl. "How Europe Matters: Different Mechanisms of Europeanization". European Integration Online Papers 1999, 7:1-19. https://papers.ssrn.com/sol3/papers.cfm?abstract_id=302746.

Koprić, Ivan et al. Europski upravni prostor. Zagreb: Institut za javnu upravu, 2012. Kuznetsov, Alexander S. Theory and Practice of Paradiplomacy. Subnational governments in international affairs. London, New York: Routledge, 2016.

Ladrech, Robert. "Europeanization and Political Parties: Towards a Framework for Analysis". Party Politics 2002, 8:4, 389-403.

Ladrech, Robert. „The Europeanization of Interest Groups and Political Parties“. In The Member States of European Union, edited by Simon Bulmer, Christian Lequesne, 317-337. Oxford: Oxford University Press, 2005.

Ladrech, Robert. Europeanization and National Politics. The European Union Series: Palgrave Macmillan, 2010.

Magnette, Paul. „How can one be European? Reflections on the Pillars of European Civic Identity“. European Law Journal 2007, 13:664-679.

Mair, Peter. "Political Parties and Party Systems". In Europeanization. New Research Agenda, edited by Paolo Graziano, Maarten P. Vink, 154-166. Houndmills, Basingstoke: Palgrave Macmillan, 2007.

Marshall, Adam J. "Europeanization at the urban level: local actors, institutions and the dynamics of multi-level interaction". Journal of European Public Policy 2005, 12:668-686.

McCormick, John. Understanding the European Union: A Concise Introduction. The European Union Series: Palgrave Macmillan, 2011.

Meyer, John W., Brian Rowan. "Institutionalized Organizations: Formal Structure as Myth and Ceremony". In: The New Institutionalism in Organizational Analysis, edited by. Walter W. Powell, Paolo J. DiMaggio, 41-62. Chicago-London: The University of Chicago Press, 1991.

Musa, Anamarija. Agencijski model javne uprave, Zagreb: Pravni fakultet Sveučilišta u Zagrebu, Studijski centar za javnu upravu i javne financije, 2014.

Olsen, Johan P. "The Many Faces of Europeanization”. Journal of Common Market Studies 2002, 5:921-952. https://doi.org/10.1111/1468-5965.00403.

Paquin, Stephane. "Paradiplomacy". In Global Diplomacy. An Introduction to Theory and Practice, edited by Thierry Balzacq, Frederic Charillon, Frederic Ramel, translated by William Snow, 49-62. Paris: Palgrave Macmillan, 2019. 
Radaelli, Claudio M., Romain Pasquier. "Conceptual Issues”. In Europeanization. New Research Agenda. edited by Paolo Graziano, Maarten P. Vink, 35-45. Houndmills, Basingstoke: Palgrave Macmillan, 2007.

Risse, Thomas, Cowles, Maria G., Caporaso, James. "Europeanization and Domestic Change: Introduction”. In Transforming Europe. Europeanization and Domestic Change. edited by Maria G. Cowles, James Caporaso, Thomas Risse, 1-20. Ithaca, London: Cornell University Press, 2001.

Rose, Richard. Learning from Comparative Public Policy. London-New York: Routledge, 2005.

Schimmelfennig, Frank, Ulrich Sedelmeier. "The Europeanization of Eastern Europe: The External Incentives Model Revisited”. Paper for the JMF@25 conference, EUI, 22/23 June 2017. https://www.eui.eu/Documents/RSCAS/ JMF-25-Presentation/Schimmelfennig-Sedelmeier-External-Incentives-Revisited-JMF.pdf.

Sbragia, Alberta, Francesco Stalfi. "Key Policies". In The European Union: How does it work?. edited by Elizabeth Bomberg, John Peterson, Alexander Stubbs, 115-137. Oxford: Oxford University Press, 2008.

Schulze, Claus J. "Cities and EU governance: policy-takers or policy-makers?". Regional and Federal Studies 2003, 13:121-147.

Sitterman, Birgit. "Europeanization - A Step Forward in Understanding Europe". https://ceses.cuni.cz/CESES-141-version1-2_1_Sittermann_Nachwuchsgruppe_on_Europeanisation_2006.pdf.

Sošić, Mario. "Europeizacija nacionalnih politika: concept i istraživački pristup". Anali hrvatskog politološkog društva 2006, 3:229-246.

Standard Eurobarometer 89, Report on European Citizenship, Spring 2018.

Stubbs, Paul. "Participacija, partnerstvo i/ili pomoć: unutarnji i vanjski dionici u održivom razvoju”. In: Participativno upravljanje za održivi razvoj, edited by Željka Kordej-De Villa, 149-166. Zagreb: Ekonomski institut Zagreb, 2009. Woźniakowski, Tomasz P., Frank Schimmelfennig, Michał Matlak, "Europeanization Revised: An Introduction". In: Europeanization Revised: Central and Eastern Europe in the European Union, edited by Michał Matlak, Frank Schimmelfennig, Tomasz P. Woźniakowski, 6-18. European University Institute, Robert Schuman Centre for Advanced Studies, 2018. 
